\title{
Green tea and its waste attract workers of formicine ants and kill their workers-implications for pest management
}

\author{
Hamady Dieng a,*, Ruzieyana Bt Mohd Zawawi ${ }^{\mathrm{b}}$, Nur Intan Saidaah Bt Mohamed Yusof ${ }^{\mathrm{b}}$, \\ Abu Hassan Ahmad ${ }^{\mathrm{b}}$, Fatimah Abang ${ }^{\mathrm{c}}$, Idris Abd Ghani ${ }^{\mathrm{d}}$, Tomomitsu Satho ${ }^{\mathrm{e}}$, \\ Hamdan Ahmad $^{\mathrm{b}}$, Wan Fatma Zuharah ${ }^{\mathrm{b}}$, Abdul Hafiz Abd Majid ${ }^{\mathrm{b}}$, \\ Nur Shilawati Abd. Latip ${ }^{c}$, Cirilo Nolasco-Hipolito ${ }^{c}$, Gabriel Tonga Noweg ${ }^{\mathrm{a}}$ \\ a Institute of Biodiversity and Environmental Conservation, Universiti Malaysia Sarawak, Kota Samarahan, Malaysia \\ ${ }^{\mathrm{b}}$ School of Biological Sciences, Universiti Sains Malaysia, Penang, Malaysia \\ ${ }^{\mathrm{c}}$ Faculty of Resource Science and Technology, Universiti Malaysia Sarawak, Kota Samarahan, Malaysia \\ d Faculty of Science and Technology, Universiti Kebangsaan Malaysia, Bangi, Malaysia \\ e Faculty of Pharmaceutical Sciences, Fukuoka University, Japan
}

\section{A R T I C L E I N F O}

\section{Article history:}

Received 18 January 2016

Received in revised form 30 March 2016

Accepted 9 May 2016

\section{Keywords:}

Ants

Tea

Tea waste

Behavioral effects

Toxicity

\begin{abstract}
A B S T R A C T
Daily, 3 billion cups of tea consumed worldwide and this consumption is accompanied by the discarding of huge waste amounts into the environment. Tea leaf contains a diverse array of toxic molecules. Despite evidence that its waste is almost as rich in toxicants as green leaves; no research has been done to turn this source of pollution into a benefit for ant pest management, where new chemistries are highly needed as a result on insecticide resistance. The present study was performed to explore the behavioral and lethal effects of tea and its leftovers on the black crazy ant (BCA), Paratrechina longicornis Latreille, yellow crazy ant (YCA), Anoplolepis gracilipes Smith, and weaver ant (WA), Oecophylla smaragdina Fabricius. Both fresh tea extract (FTE) and used tea extract (UTE) were detrimental to the survival of BCA, YCA, and WA. FTE was the most toxic solution and BCA was the most vulnerable species. The presence of tea extracts in meals did not prevent workers of all three species from visiting and feeding in the presence their preferred foods. The results presented here suggest that diets containing tea extracts are attractive to BCA, YCA, and WA when in competition with their preferred foods. These extracts were also insecticidal to the worker ants. These properties demonstrate the potential of tea and its waste products for developing novel environmentally friendly and low-cost ant control strategies, which could also be a practical solution to the growing environmental problem it causes.
\end{abstract}

(c) 2016 Elsevier B.V. All rights reserved.

\section{Introduction}

Tea (Camellia sinensis; Ericales: Theaceae), which is mainly cultivated in tropical climates (Sarma et al., 2014), is the most widely consumed beverage aside from water in many countries around the world (Primavesi et al., 2014). This consumption is accompanied by the discarding of large amounts of tea waste into the environment (Guardian News, 2014). World tea production and consumption are forecast to significantly increase from during the period 2014-2020 (Transparency Market Research, 2015). Tea

\footnotetext{
* Corresponding author at: Institute of Biodiversity and Environmental Conservation, Faculty of Resource Science and Technology, Universiti Malaysia Sarawak, Kota Samarahan, Malaysia.

E-mail address: hamachan1@yahoo.com (H. Dieng).
}

leaves contain hundreds of chemicals including flavonoids, phenolic compounds, alkaloids and methylxanthines. With the predicted increase in popularity of tea as a beverage, the amounts of tea waste in the environment along with the huge chemical resources that they contain are both expected to increase.

Tea has an array of positive health benefits in humans (Johnson et al., 2012; The Tea Association of the USA Inc., 2013) and negative effects on bacterial and viruses (Heinrich et al., 2011). Tea can also have negative effects on insects. Mitchell et al. (1993) reported increased anti cytochrome P-450-dependent ecdysone 20-monooxygenase activities of flavonoids in dipterans and lepidopterans. Chlorogenic acid has been shown to cause death (Nathanson, 1984), reduce feeding and the bioavailability of amino acids and to decrease digestion in several insects (Dowd and Vega, 1996; Jassbi, 2003; Mallikarjuna et al., 2004). 